\title{
Balchaturbhadra churna as a potential medicine for SARS-Cov2 infection in pediatric setting: An In-Silico study
}

\author{
Kuldeep Choudhary ${ }^{1}$, Saketh Ram Thrigulla ${ }^{2}$, Manohar Gundeti ${ }^{1}$, Pratyusha Mantena ${ }^{2}$ \\ Shruti Koulgi ${ }^{3}$, Vinod Jani ${ }^{3}$, V. N. Mallikarjunachari Uppuladinne ${ }^{3}$, Uddhavesh \\ Sonavane $^{3}$, Rajendra Joshi ${ }^{3}$, Goli Penchala Prasad ${ }^{2}$, R. Govind Reddy ${ }^{1}$, \\ Srikanth Narayanam ${ }^{4}$
}

\begin{abstract}
:
Background: Balchaturbharda Churna (BC), is four ingredients (Aconitum heterophyllum Wall. Ex Royle, Pistacia integerrima stew. Ex brandis, Piper Longum Linn. and Cyperus rotundus linn.) Ayurvedic powder dosage form, which is commonly prescribed for treating fever, cough, diarrhea in pediatric setting.

Objective: This present study evaluates the possible effect of phytochemicals from the ingredients of $\mathrm{BC}$ on SARS-CoV-2 main protease $\left(\mathrm{M}^{\mathrm{Pro}}\right)$, RNA dependent RNA polymerase (RdRP) and spike-ACE2 (SA) complex through in silico evaluation.

Materials and methods: X-ray crystal structure of $M^{\text {Pro }}$ and SA complex with PDB IDs 6LU7 and 6LZG and the SWISS model of RdRP were used as the drug targets. An enhanced docking methodology has been implemented to perform the molecular docking of these phytochemicals against the above-mentioned drug targets of SARS-CoV-2. DOCK 6 was used to perform docking of these phytochemicals. The ADMET and drug likeliness properties for these selected phytochemicals was performed using SWISS ADME.

Results: The ensemble docking studies suggest that aconitine, lappaaconitine from Aconitum heterophyllum, 2'-hydroxyisorientin from Pistacia intergerrima and guineesine, pipercide and piperoic acid from Piper longum hold the potential to bind favorably with the SARS-CoV-2 drug targets. The drug likeliness and ADMET properties were calculated for these phytochemicals indicate that all the three phytochemicals from Piper longum were observed to have considerate drug-likeliness and ADMET properties. Aconitine has molecular weight slightly higher than $500 \mathrm{kDA}$ and has more than 10 hydrogen bond acceptors.

Conclusion: The in-silico study demonstrates that phytochmeicals from the ingredients BC viz., aconitine, lappaaconitine from Aconitum heterophyllum, 2'-hydroxyisorientin from Pistacia intergerrima and guineesine, pipercide and piperoic acid from Piper longum hold the potential to bind favourably with the SARS-CoV-2 drug targets. The study also provides evidence for drug likeliness and ADMET properties for these phytochemicals suggesting that $\mathrm{BC}$ can be further studied as potential drug of choice for treating SARSCoV-2infection in paediatric cases.
\end{abstract}

Keywords: COVID-19, SARS-CoV-2, Balchaturbhadra, Molecular Docking, Aconitum heterophyllum, Pistacia Integerrima, Piper Longum, Cyperus rotundus, Ativisha, Shringi, Pippali, Musta, Ayurveda, in-silico study, ensemble docking

1. CCRAS - RRAP Central Ayurveda Research Institute, Mumbai - 18, Maharashtra, India.

2. CCRAS-National Institute of Indian Medical Heritage, Revenue Board Colony, Gaddiannaram, Hyderabad, 500036, Telangana, India.

3. High Performance Computing-Medical and Bioinformatics Applications Group, Centre for Development of Advanced Computing, Panchavati, Pashan, Pune, 411027, Maharashtra, India.

4. Central Council for Research in Ayurvedic Sciences, JLNBCAH Anusandhan Bhavan, No.61-65, Institutional Area, Opp. 'D' Block, Janakpuri, New Delhi - 110058, India. 


\section{Balchaturbhadra churna as a potential medicine for SARS-Cov2 infection in pediatric setting: An In-Silico study}

\section{Introduction}

Coronavirus disease 2019 (COVID-19) is caused by highly contagious virus strain SARS-Coronavirus 2 (SARS-CoV-2), mainly characterized by fever and respiratory symptoms. Complications such as acute respiratory distress syndrome (ARDS) and death are primarily seen in the elderly, and in Covid-19 individuals with co-morbidities for example hypertension, obesity or chronic kidney disease ${ }^{1}$. In comparison with adults, the global incidence of Covid-19 disease in children is strikingly lower. Children of all ages can get COVID-19 but those younger than 12 to 14 years of age appears to be affected less commonly than adults. In surveillance from various countries children account for up to $15 \%$ of laboratory confirmed SARS-CoV-2 cases $^{2}$.

The lower observed prevalence of Covid-19 in pediatric age group worldwide is partially attributed to widespread school closures in response to the pandemic. Furthermore, challenges in the adequate screening and testing of children especially those who are asymptomatic and mildly symptomatic may have underestimated the reporting of covid-19 cases in children ${ }^{3,4}$. The symptoms of COVID-19 are similar in children and adults, but the frequency of symptoms varies. In general, $90 \%$ of children positive for SARS-CoV-2 infection are asymptomatic or have mild to moderate symptoms with better outcome ${ }^{5,6}$. In rare cases, a post infectious disease, characterized by multisystem inflammatory syndrome in Children (MIS-C), Kawasaki - like symptoms and acute heart failure can occur, but in general children have a very low risk of death ${ }^{7}$.

India has seen a devastating second wave due to the Delta variant with increased morbidity and mortality compared with first wave ${ }^{8}$. There were media reports of drastic increase in number of cases in children with SARS-CoV-2 infection in comparison to first wave, and with more concerns of rising post infectious life-threatening complications in children $2-4$ weeks after contracting Covid-19 infection ${ }^{9-11}$.

As the second wave of Covid-19 was ebbing amid accelerated vaccination drive among adult and elderly population, India has recently seen a sharp rise in Covid-19 cases over the past few weeks. At the time of writing current manuscript, daily cases increased from 6,531 on Dec. 26, 2021, to 2,38,018 on Jan. 17, 2022, a 36-fold increase in 22 days, which has sparked a fear that a third wave driven by Omicron is around the corner ${ }^{12}$.

The World Health Organization (WHO) on November 26, 2021 declared the Omicron (B.1.1.529 strain of Covid-19), first detected in South Africa, to be a variant of concern due to several mutations including 15 mutations in the receptor-binding domain (RBD) of spike protein as well as increased transmissibility. Several studies have raised concern about Omicron evading the antibodies thus increasing the chances of reinfection as well as breakthrough infections. Nevertheless, the findings are of preliminary nature and more clarity will be evident in coming weeks ${ }^{13,14}$.

Govt. of India has rolled out Covid-19 vaccination drive for children in staggered manner phase with first group of $15-18$ years of age getting jab from $3^{\text {rd }}$ January, 2022. Amid sharp rise in cases, there are reports of rising infection in young children with many of those infected by the virus showing symptoms such as fever, cough, chills, diarrhea and 
respiratory problems. Experts believe that the actual number of positive cases may be under reported due to less number of RT - PCR test in young children ${ }^{15,16}$.

The COVID-19 pandemic has considerably increased the demand to develop faster therapeutics to overcome any such global emergency. Ayurveda, being one of the most trusted modes of traditional medicine has proved to be a boon for patients recovering from COVID-19.

To note, AYUSH system has considerably played a major role by undertaking several R\&D activities and public health initiatives to harness the potential of AYUSH systems to contain the impact of the COVID-19 pandemic ${ }^{17}$.To it recent success, various interventional clinical trials undertaken in asymtomatic, mild to moderate COVID-19 infections have shown positive results in combating covid-19 infection. In this context, multicentric clinical trial of Ayurvedic formulation Ayush -64 (developed by Central Council for Research in Ayurvedic Sciences, New Delhi) as add on to Standard care of treatment have shown early clinical recovery response in Covid-19 contracted patients ${ }^{18}$.

With the lessons learned from second wave, the Government of India has taken several steps at various levels to ramp up the existing health care facilities for children to prepare for sudden surge of COVID-19 cases in the pediatric age group. In this context, the Ministry of Health and Family Welfare (MOHFW) and Ministry of Ayush (MoA), two pillars of Indian health care system to Govt. of India have issued operational guidelines and advisories for prevention and mitigation of Covid-19 in children ${ }^{19,20}$. MoA released home care guidelines for children and advisory for AYUSH practitioners about prophylactic care in children during the covid-19 pandemic. Formulations like Ayush-64, Balchaturbhadra churna, Sitopaladi churna etc. have been incorporated for symptomatic care of covid-19 pediatric patients ${ }^{21}$.

Balchaturbhadra churna (BC) is a polyherbal formulation mentioned in classical Ayurvedic texts specifically indicated for fever (Jvara), cough (Kasa) and diarrhea (Atisaara) in children. It consists of four ingredients viz., Aruna=Ativisha (Aconitum heterophyllum Wall. Ex Royle), Shringi (Pistacia integerrima stew. Ex brandis), Krisna=Pippali (Piper Longum Linn.) and Ghana=Musta (Cyperus rotundus linn. $)^{22-25}$.

The Ayurvedic pharmacological profile of individual medical plants used in $\mathrm{BC}$ is provided in table number two $\mathrm{o}^{26-30}$. To summarize it, the formulation is characterized predominantly by katu (pungent) - tikta (bitter) rasa (taste), kapha-vata dosha har (pacifies kapha and Vata dosha), ushna veerya (hot potency), and with deepana (digestion and metabolism enhancer) - pachana (digestive enhancer) properties it is therefore indicated in Jvara (fever), Kasa (cough) and Atisaara (diarrhea). The combined effects of these herbs render this compound as a potent combination against conditions presenting with symptoms of cough/cold, fever and diarrhea, as found in Flu-like Viral Illnesses.

The chemical compounds found in the ingredients of $\mathrm{BC}$ have been reported to exhibit several pharmacological properties like anti-pyretic, anti-inflammatory, antioxidant, anti-diarrheal, anti-platelet etc. (see table no.3) ${ }^{31-65}$. Pre-clinical pharmacological and toxicological studies have been undertaken to study its safety aspect (table no.4). The acute toxicity experiment did not produce any signs and symptoms of toxicity up to the dose of $2000 \mathrm{mg} / \mathrm{kg}$ but at dose of $900 \mathrm{mg} / \mathrm{kg}$ given for 45 days has shown mild toxic potential $^{66}$. 
In order to understand the role of these formulations in targeting the crucial proteins of SARS-CoV-2 an in-silico molecular docking study has been performed. The phytochemicals that are present in the formulation of $\mathrm{BC}$ have been docked against three important drug targets of SARS-CoV-2, namely, main protease $\left(\mathrm{M}^{\text {Pro }}\right)$, RNA dependent RNA polymerase (RdRP) and spike protein. The spike protein of SARS-CoV-2 binds to the ACE2 receptor present on the human cells. Hence, the been considered as the target in the present study. The X-ray crystal structure of $\mathrm{M}^{\text {Pro }}$ and SA complex with PDB IDs 6LU7 and 6LZG and the SWISS model of RdRP were used as the drug targets ${ }^{67-69}$. Figure no. 1 shows the structure of these three drug targets along with the drug-binding region marked in red dashed circle.

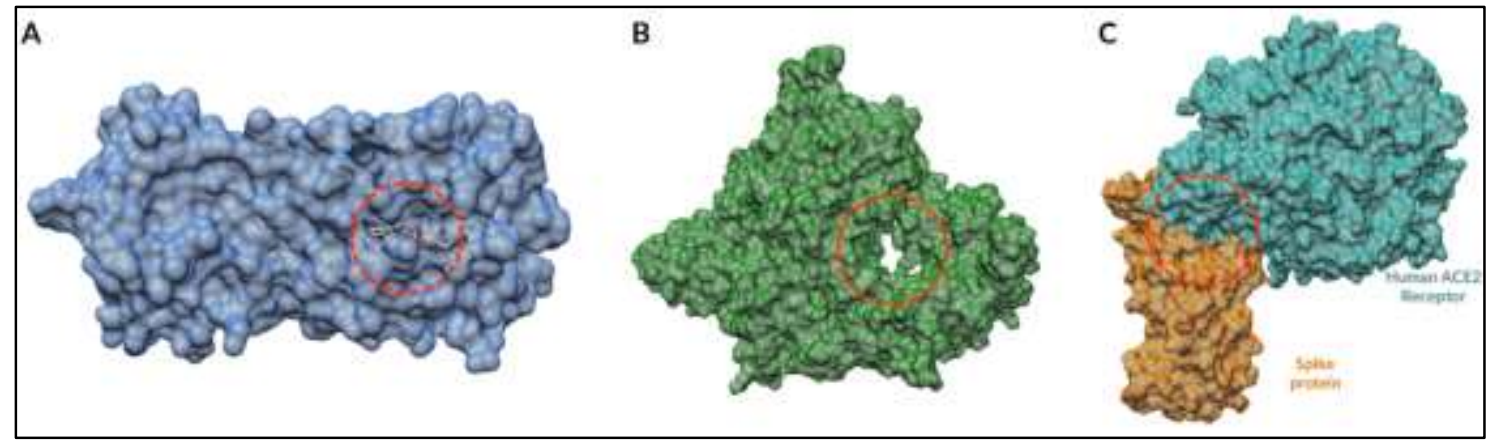

Figure 1:(A) $\mathrm{M}^{\text {Pro }}$ bound to $\mathrm{N} 3$ as in $6 \mathrm{LU} 7,(\mathrm{~B}) \mathrm{RdRP}$ with RNA primer binding region circled in red and (C) SA complex from 6LZG with the interaction site circled in red.

These three drug targets were docked using a set of 32 phytochemicals that belonged to the formulation of BC. These phytochemicals are isolated from four of BC ingredients, namely, Aconitum heterophyllum, Pistacia integerrima, Piper longum and Cyperus rotundus. The 2D representation for these phytochemicals as given in PubChem database has been shown in the Figure 2. 


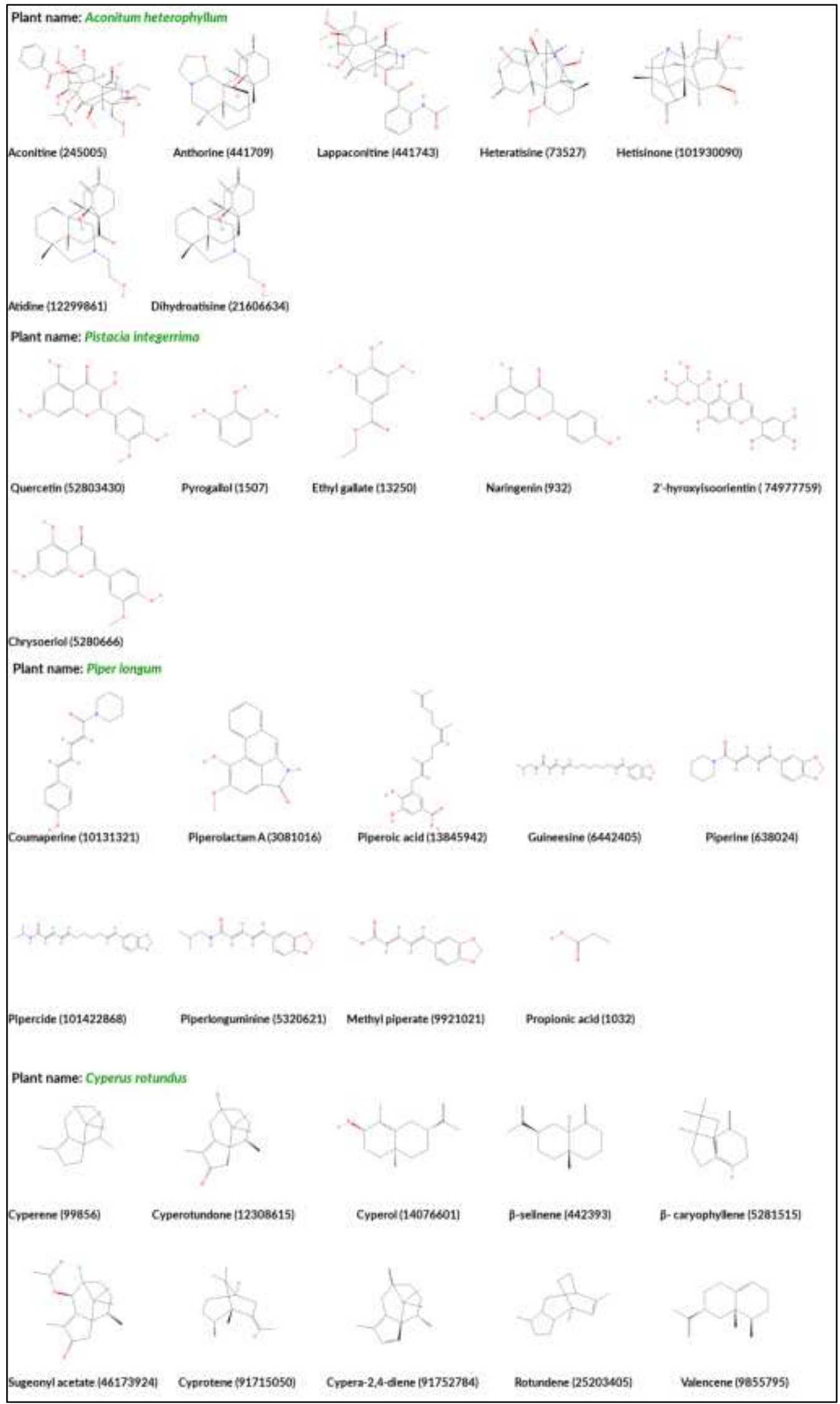

Figure 2: Name and PubChem Compound ID (CID) (in brackets) of the phytochemicals present in the BC (Balchaturbhadra churna) 
An enhanced docking methodology has been implemented to perform the molecular docking of these phytochemicals against the above-mentioned drug targets of SARS-CoV2. This methodology has been termed as ensemble docking, where in multiple structural instances of the drug targets are docked instead of just a single experimental or computational model. This methodology has been reported in few of our earlier works ${ }^{70-}$ 72 .

\section{Methodology}

The methodology used to perform ensemble docking has been adapted from three of our earlier works on in-silico docking of small molecules to $\mathrm{M}^{\text {Pro70 }}, \mathrm{RdRP}^{71}$ and SA complex ${ }^{72}$. Figure 3 explains this methodology in details.

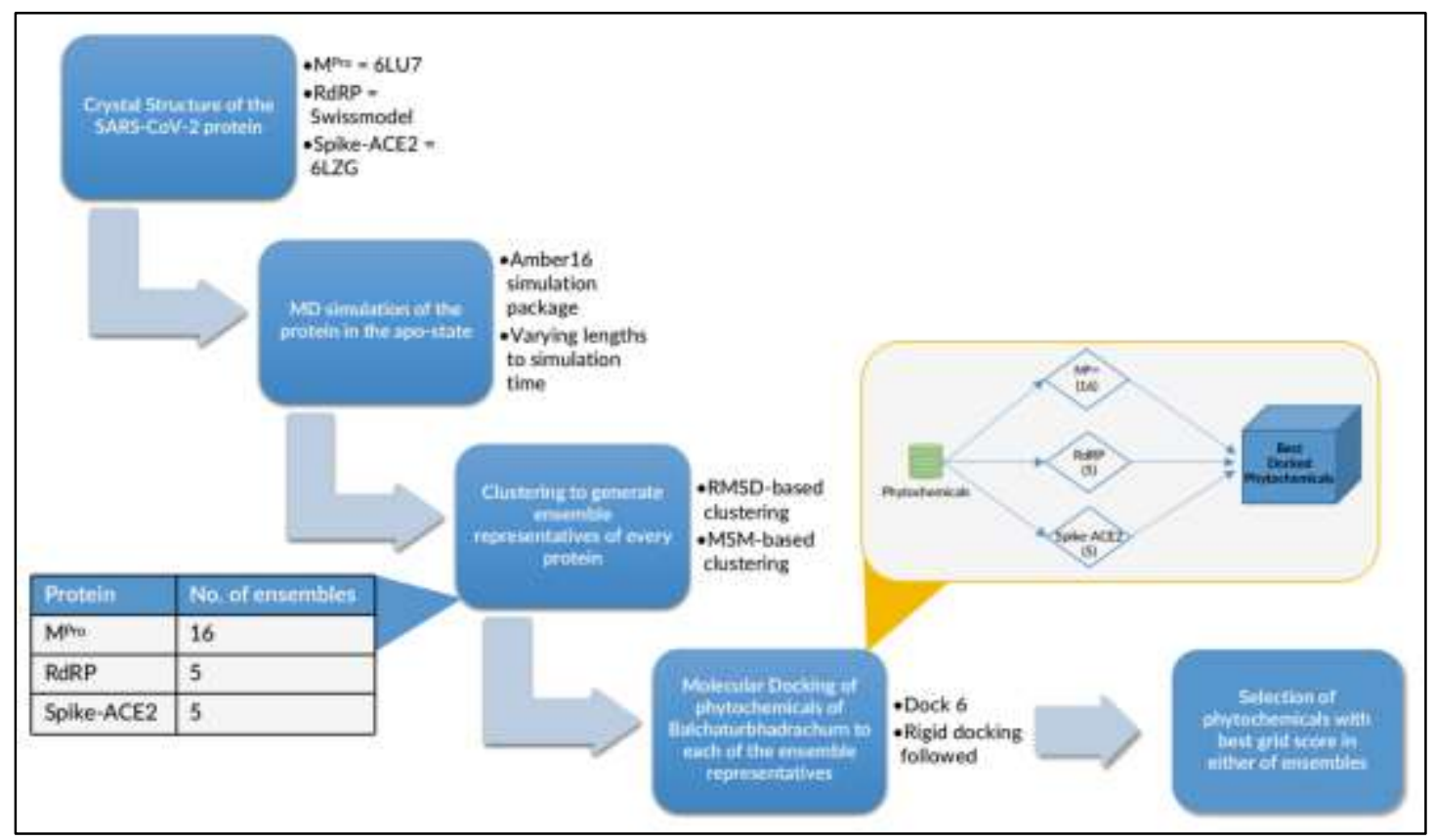

Figure 3: Protocol followed for identifying the best docked phytochemicals of BC (Balchaturbhadra churna)

The simulation data generated from the step mentioning "MD simulation of the protein in the apo-state" was used from three of our previous works ${ }^{70-72}$. AMBER 16 simulation package was used for these simulations ${ }^{73}$. A total of 16,5 and 5 ensemble representatives of $\mathrm{M}^{\mathrm{Pro}}$, RdRP and SA complex were docked using the 32 phytochemicals of Balchaturbhadra churna. DOCK 6 was used to perform docking of these phytochemicals ${ }^{74}$. The rigid docking protocol was followed for the same. DOCK 6 assigns a grid score for each of the molecules that are docked against the drug targets. These grid scores are energy values and hence, lower the energy better is the binding of the molecules to the drug targets. The grid score is calculated using the force field equation as given below.

$$
E=\sum_{i=1}^{\operatorname{lig}} \sum_{j=1}^{\mathrm{rec}}\left(\frac{A_{i j}}{r_{i j}^{a}}-\frac{B_{i j}}{r_{i j}^{b}}+332 \frac{q_{i} q_{j}}{D r_{i j}}\right)
$$


$\mathrm{E}$ is the grid score, $\mathrm{i}$ and $\mathrm{j}$ are the number of atoms belonging to ligands (phytochemicals), denoted as lig and receptor (drug targets) denoted as rec, respectively. $\frac{A_{i j}}{r_{i j}^{a}}-\frac{B_{i j}}{r_{i j}^{b}}$ represents the contribution due to van der Waals interactions. The term $332 \frac{q_{i} q_{j}}{D_{i j}}$ represents the contribution due to electrostatics interactions.

DOCK 6 ranks these phytochemicals based on their grid scores in each of the ensembles. Apart from ensemble docking, direct docking to the experimental and computational models known through literature (Figure 1) was also performed. Based on these grid scores, the phytochemicals that ranked $1^{\text {st }}$ in either of the ensembles or the experimental/computational model were selected. There were instances where some phytochemicals were either ranked $1^{\text {st }}$ in more than one ensemble or not ranked $1^{\text {st }}$ in any ensemble. The interaction analysis for such instances were performed using the LigPlot software $^{75}$. The ADMET and drug likeliness properties for these selected phytochemicals was performed using SWISS ADME ${ }^{76}$.

\section{Results}

\section{Targeting the MPro}

The selected phytochemicals that showed the best grid score in either of the ensembles or the experimental/computational model were identified. Figure 4 shows the grid scores for the selected phytochemicals when docked against $\mathrm{M}^{\text {Pro }}$ and the residues that show interactions with these selected phytochemicals.

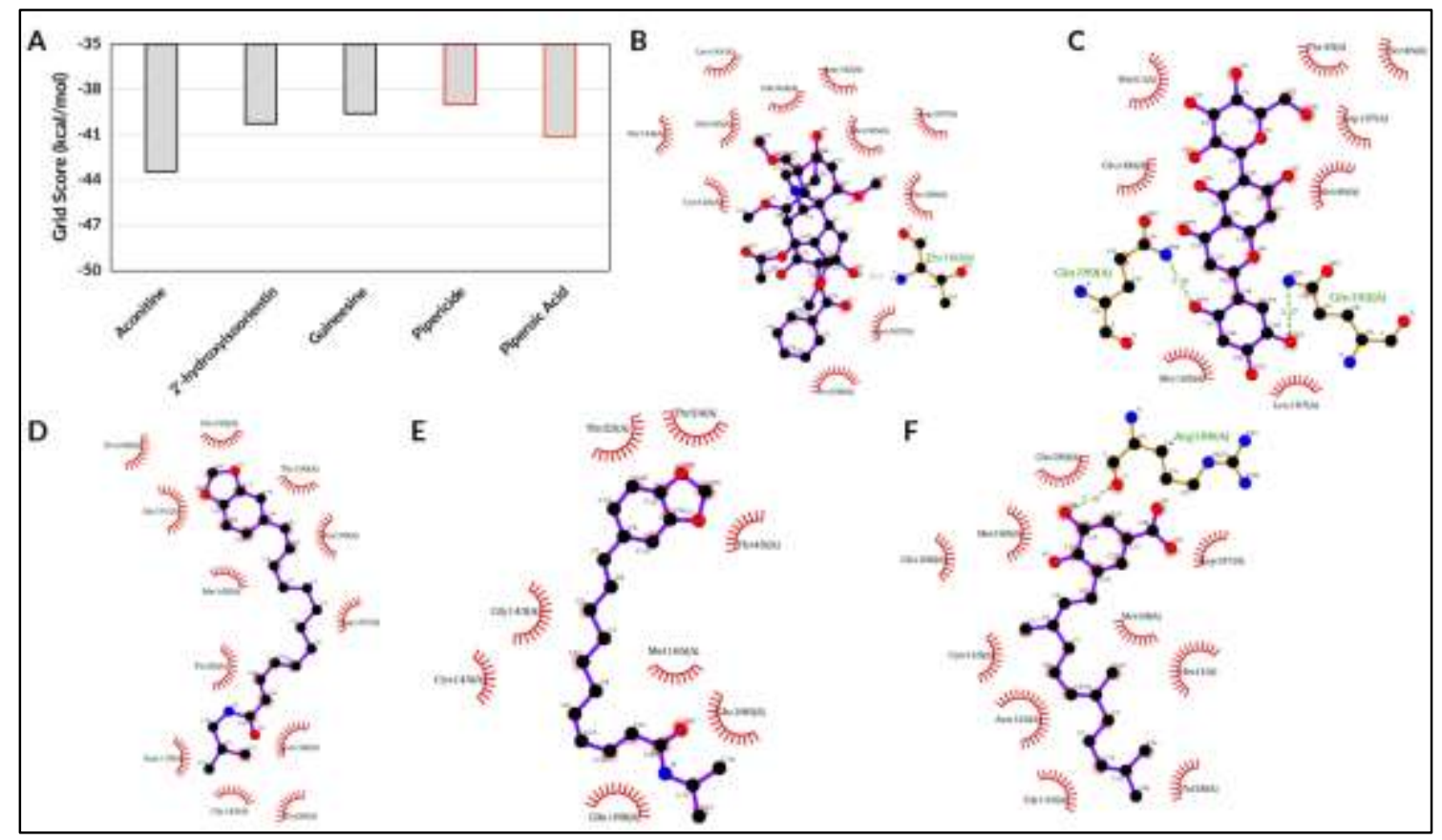

Figure 4: (A) Ligands with best grid score obtained on docking to either of the 16 ensembles or the 6LU7 (marked in red) of MPro. Interactions between (B) aconitine, (C) 2'-hydroxyisoorientin, (D) guineesine, (E) pipercide and $(\mathrm{F})$ piperoic acid

The ensemble docking in case of MPro consisted of 16 ensemble states captured through Root Mean Square Deviation (RMSD)-based clustering and Markov State Modeling (MSM)-based clustering ${ }^{67}$. One of our earlier research articles, mentions the details about these 16 ensembles (Figure 5 of Koulgi et.al. 2020) ${ }^{67}$. The 32 phytochemicals from $\mathrm{BC}$ were docked individually on these 16 ensembles and also on the X-ray crystal 
structure 6LU7. The phytochemicals aconitine, 2'-hydroxyisoorientin, guineesine, pipercide and piperoic acid ranked $1^{\text {st }}$ in either one of the ensembles or 6LU7. Figure 4A shows the best grid scores obtained. Aconitine, 2'-hydroxyisoorientin, and guineesine had the best grid scores amongst the 16 ensembles. However, pipercide and piperoic acid had the best grid scores when docked to 6LU7. Figure 4B-F show the interactions made by aconitine, 2'-hydroxyisoorientin, guineesine, pipercide and piperoic acid with the residues of $\mathrm{M}^{\text {Pro }}$. The red color represents hydrophobic interactions and the hydrogen bonding interactions have been represented by green dashed lines. Aconitine was observed to form a hydrogen bond with T190 of $\mathrm{M}^{\text {Pro }}$ (Figure 4 B). 2'-hydroxyisoorientin formed a hydrogen bond with Q189 and Q192 of $\mathrm{M}^{\text {Pro }}$ (Figure 4 C). Guineesine and pipercide formed only hydrophobic interactions with residues of MPro (Figure 4D and E). R188 formed a hydrogen bond with piperoic acid (Figure 4F). These interactions were seen in docked states with most favorable grid scores. Hence, it can be inferred that these interactions are energetically favorable and may prove beneficial for bringing in the inhibitory effect.

\section{Targeting the RdRP}

Figure 5 shows the grid scores for the three phytochemicals selected when docked against RdRP and their interaction with the residues of this drug target.

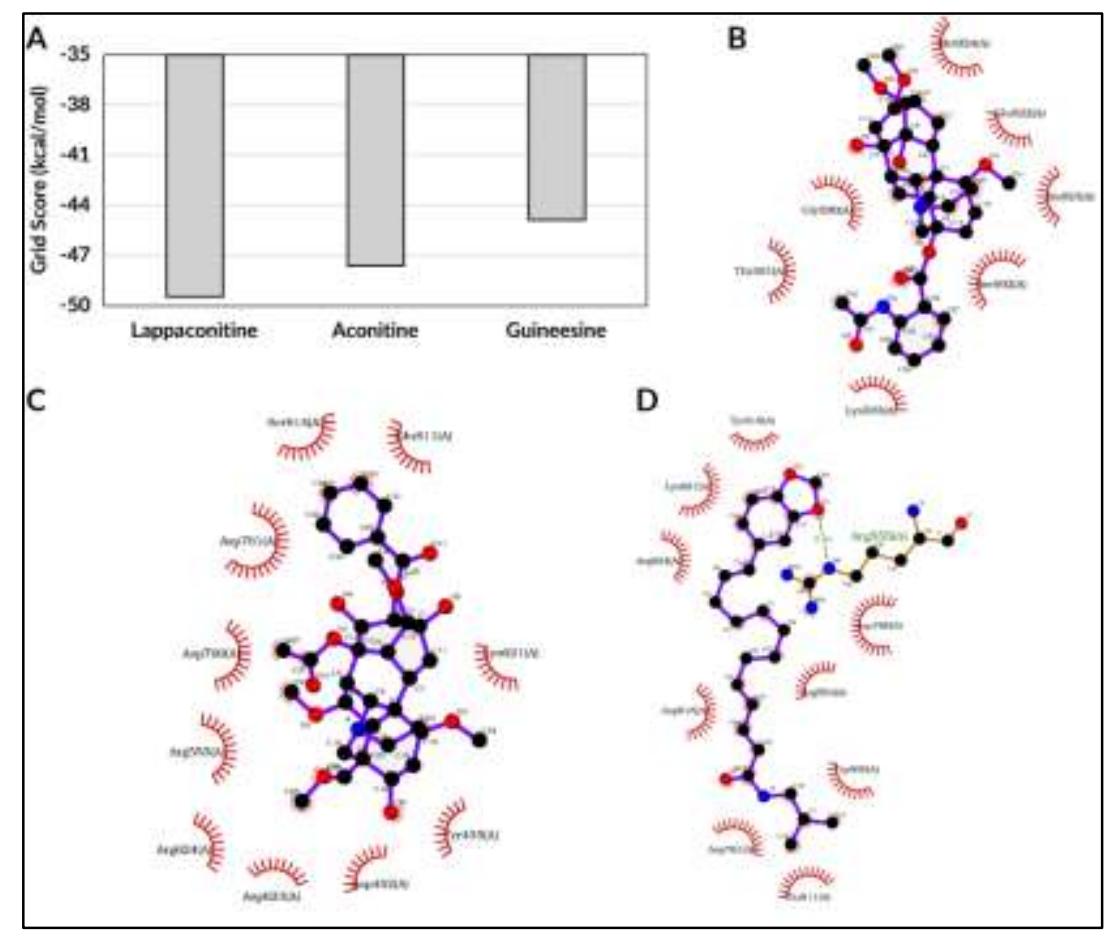

Figure 5: (A) Ligands with best grid score obtained on docking to either of the 5 ensembles of RdRP. Interactions between (B) lappaconitine, (C) aconitine, and (D) guineesine.

In case of ensemble docking to RdRP protein of SARS-CoV-2, a total of 5 ensemble representatives were considered. One of our earlier works on drug repurposing studies with RdRP mentions about the method used to generate these ensemble representatives ${ }^{68}$. Among the 32 phytochemicals from the $\mathrm{BC}$, only 3 of them ranked $1^{\text {st }}$ in either of the 5 ensemble representatives. The value of the grid score was also observed to be lower in them as compared to the ones obtained on docking to the computational model. These three phytochemicals were lappaconitine, aconitine and guineesine. Lappaconitine and aconitine were observed to form multiple hydrophobic interactions with the residues of the RdRP (Figure 5 B and C). Guineesine was observed to form hydrogen bonding with R555 of 
RdRP (Figure 5 D). The critical and conserved residues of RdRP, namely D760, D761 which are known to bind to the RNA primer were observed to be interacting with these phytochemicals ${ }^{77}$. R555 is known to be one of the crucial residues involved in inhibitor binding ${ }^{77}$.

\section{Targeting the spike-ACE2 interface}

Figure 6 shows the grid scores for the phytochemicals that were observed to rank $1^{\text {st }}$ in either of the 5 ensembles or the crystal structure 6LZG. These ensemble states were earlier reported in one of our works on spike-ACE2 complex ${ }^{72}$. Figure 6 A depicts that lappaconitine showed the best grid score followed by aconitine, guineesine and pipercide. The former too were observed to show good binding to either of the 5 ensembles. However, guineesine and pipercide were observed to bind with better grid scores to the crystal structure 6LZG. Figure 6 B-E shows the interacting residues from the spike protein and human ACE2 receptor with the respective phytochemicals.

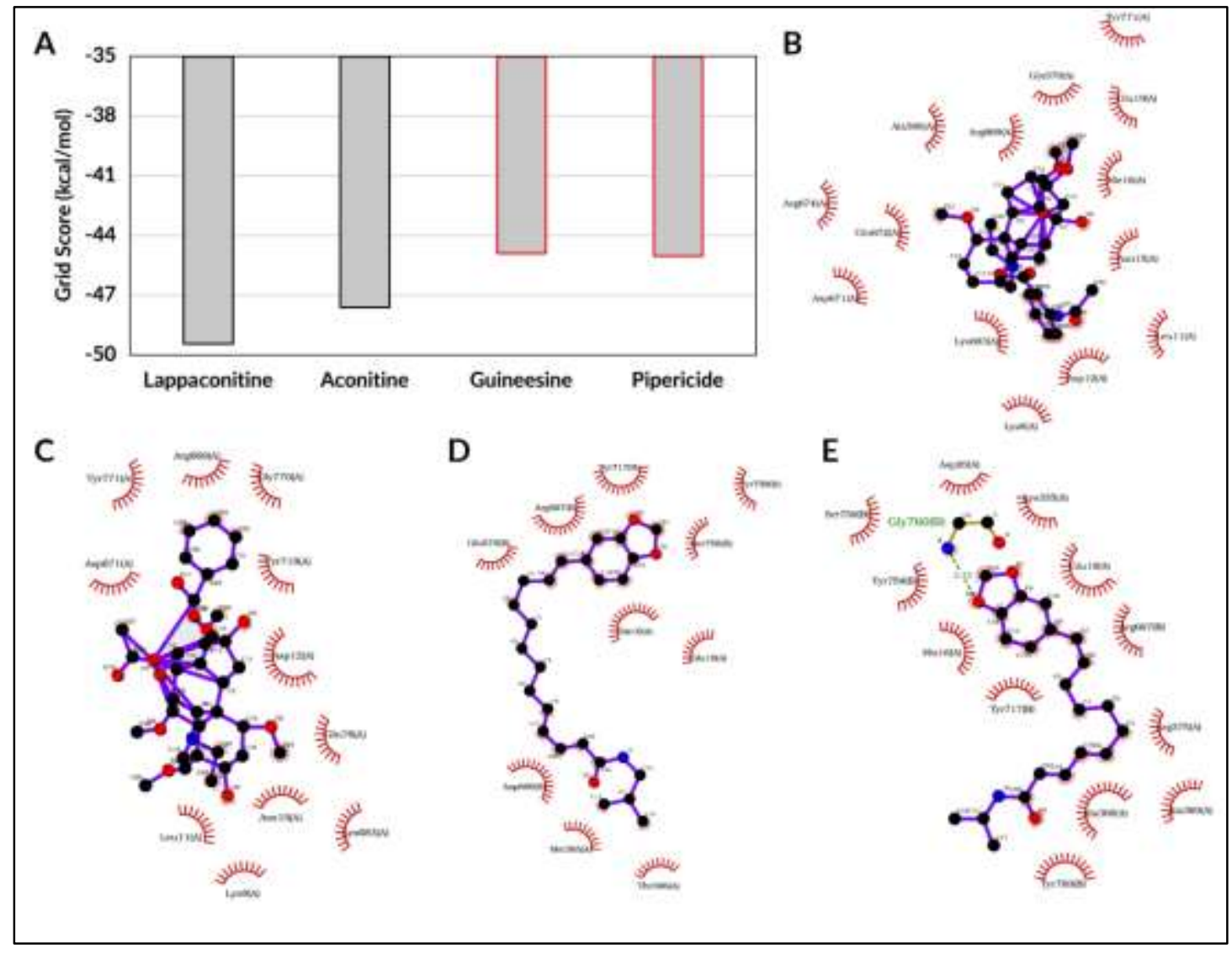

Figure 6: (A) Ligands with best grid score obtained on docking to either of the 5 ensembles or the 6LZG (marked in red) of SA complex. Interactions between (B) lappaconitine, (C) aconitine, (D) guineesine, and (E) pipercide.

The residues with A in brackets belong to spike protein, whereas B in brackets belongs to the human ACE2 receptor. Multiple residues from both the proteins were observed to form hydrophobic interactions with these phytochemicals. Most of these residues are observed to interact with one another to form a stable spike-ACE2 complex. However, these interactions suggest that the presence of these phytochemicals at the interface may be interfering the spike-ACE2 interactions. 


\section{Drug likeliness of phytochemicals}

The ensemble docking studies suggest that aconitine, lappaaconitine from Aconitum heterophyllum, 2'-hydroxyisorientin from Pistacia intergerrima and guineesine, pipercide and piperoic acid from Piper longum hold the potential to bind favorably with the SARSCoV-2 drug targets. The medicinal properties of these plants have been known since long in traditional medicine, hence, understanding the drug likeliness of the phytochemical would prove beneficial to support their potential as SARS-CoV-2 inhibitors ${ }^{78-82}$. The drug likeliness and ADMET properties were calculated for these phytochemicals. Table 1 shows these details for the above-mentioned phytochemicals. Aconitine has molecular weight slightly higher than $500 \mathrm{kDA}$ and has more than 10 hydrogen bond acceptors. Expect these most of the other parameters are observed to be considerable. All the three phytochemicals from Piper longum were observed to have considerate drug-likeliness and ADMET properties.

\section{Conclusion:}

Considering the possibility of pediatric population getting affected in the possible third wave of COVID-19 pandemic there is a need to identify potential, safe medicines. BC, an Ayurvedic powder dosage form is a regularly prescribed medicine to treat fever, cough, diarrhea in pediatric setting. Further, it has been included in the treatment protocols released by Ministry of Ayush for treating asymptomatic, mild cases of COVID-19. The in-silico study demonstrates that phytochmeicals from the ingredients $\mathrm{BC}$ viz., aconitine, lappaaconitine from Aconitum heterophyllum, 2'-hydroxyisorientin from Pistacia intergerrima and guineesine, pipercide and piperoic acid from Piper longum hold the potential to bind favorably with the SARS-CoV-2 drug targets. The study also provides evidence for drug likeliness and ADMET properties for these phytochemicals suggesting that $\mathrm{BC}$ can be further studied as potential drug of choice for treating SARS-CoV-2 infection in pediatric cases.

Funding: This research received no external funding.

Conflicts of Interest: The authors declare no conflict of interest 
Table no. 1: Ingredients of Balchaturbhadra churna ${ }^{22}$ -

\begin{tabular}{|l|l|l|l|l|l|}
\hline $\begin{array}{l}\text { Sl. } \\
\text { No. }\end{array}$ & $\begin{array}{l}\text { Name of } \\
\text { Ingredients }\end{array}$ & Latin name & Family & $\begin{array}{l}\text { Parts } \\
\text { used }\end{array}$ & Proportion \\
\hline 1 & Aruna (Ativisha) & $\begin{array}{l}\text { Aconitum } \\
\text { Heterophyllum } \\
\text { Wall. Ex } \\
\text { Royle }\end{array}$ & Ranunculaceae & Root & 1 part \\
\hline 2 & $\begin{array}{l}\text { Shringi } \\
\text { (Karkatashringi) }\end{array}$ & $\begin{array}{l}\text { Pistacia } \\
\text { Integerrima } \\
\text { stew. Ex } \\
\text { Brandis }\end{array}$ & Anacardiaceae & Gall & 1 part \\
\hline 3 & Krisna (Pippali) & $\begin{array}{l}\text { Piper Longum } \\
\text { Linn. }\end{array}$ & Piperaceae & Fruit & 1 part \\
\hline 4 & $\begin{array}{l}\text { Ghana } \\
\text { (Musta/Nagarmotha) }\end{array}$ & $\begin{array}{l}\text { Cyperus } \\
\text { rotundus Linn. }\end{array}$ & Cyperaceae & Rhizome & 1 part \\
\hline
\end{tabular}

(Reference - As per The Ayurvedic Formulary of India (AFI, Part- I )7: 24 Balchaturbhadrika churna (Bhaisajyaratnavali, Balarogadhikara:40)

Table no. 2: Ayurvedic pharmacological profile of medicinal plants in Balchaturbhadra churna ${ }^{26-30}$ :

\begin{tabular}{|c|c|c|c|c|c|c|c|}
\hline $\begin{array}{c}\text { Name of } \\
\text { medicinal } \\
\text { plant }\end{array}$ & $\begin{array}{c}\text { Rasa } \\
\text { (taste) }\end{array}$ & $\begin{array}{c}\text { Guna } \\
\text { (properti } \\
\text { es) }\end{array}$ & $\begin{array}{c}\text { Virya } \\
\text { (poten } \\
\text { cy) }\end{array}$ & $\begin{array}{c}\text { Vipaka } \\
\text { (Bio- } \\
\text { transfor } \\
\text { med } \\
\text { rasa) }\end{array}$ & $\begin{array}{c}\text { Doshagh } \\
\text { nata } \\
\text { (pacifies } \\
\text { Dosha) }\end{array}$ & $\begin{array}{c}\text { Karma } \\
\text { (Therapeu } \\
\text { tic action) }\end{array}$ & $\begin{array}{l}\text { Vyadhi har } \\
\text { ( Curative) }\end{array}$ \\
\hline $\begin{array}{l}\text { Aconitum } \\
\text { Heterophy } \\
\text { llum Wall. }\end{array}$ & $\begin{array}{l}\text { Katu } \\
\text { (pungent } \\
\text { ) } \\
\text { Tikta } \\
\text { (bitter) }\end{array}$ & $\begin{array}{l}\text { Laghu } \\
\text { (lightness } \\
\text { ), } \\
\text { Ruksha(d } \\
\text { ryness) }\end{array}$ & $\begin{array}{l}\text { Ushna } \\
\text { (hot) }\end{array}$ & $\begin{array}{l}\text { Katu } \\
\text { (pungent) }\end{array}$ & $\begin{array}{l}\text { Kapha - } \\
\text { Pitta har } \\
\text { (pacifies } \\
\text { Kapha\& } \\
\text { Pitta } \\
\text { dosha) }\end{array}$ & $\begin{array}{l}\text { Pachana } \\
\text { (digestion } \\
\text { and } \\
\text { metabolism } \\
\text { enhancer), } \\
\text { Deepana } \\
\text { (digestive } \\
\text { enhancer) }\end{array}$ & 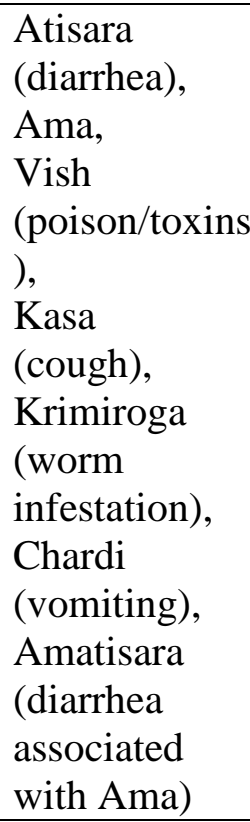 \\
\hline $\begin{array}{l}\text { Pistacia } \\
\text { Integerrim } \\
a \text { stew. ex } \\
\text { Brandis }\end{array}$ & $\begin{array}{l}\text { Tikta } \\
\text { (bitter) } \\
\text { Kashay } \\
\text { (astringe } \\
\text { nt) }\end{array}$ & $\begin{array}{l}\text { Guru } \\
\text { (heavines } \\
\text { s) }\end{array}$ & $\begin{array}{l}\text { Ushna } \\
\text { (cold) }\end{array}$ & $\begin{array}{l}\text { Katu } \\
\text { (pungent) }\end{array}$ & $\begin{array}{l}\text { Kapha- } \\
\text { Vata har } \\
\text { (pacifies } \\
\text { Kapha\& } \\
\text { Vatadosh } \\
\text { a) }\end{array}$ & $\begin{array}{l}\text { Kasahara } \\
\text { (cough } \\
\text { reliving) } \\
\text { Hikkanigra } \\
\text { hana } \\
\text { (hiccough } \\
\text { relieving) }\end{array}$ & $\begin{array}{l}\text { Jwara } \\
\text { (pyrexia), } \\
\text { Shwasa } \\
\text { (breathing } \\
\text { difficulty), } \\
\text { Urdhavata }\end{array}$ \\
\hline
\end{tabular}




\begin{tabular}{|c|c|c|c|c|c|c|c|}
\hline & & & & & & & $\begin{array}{l}\text { (obstruction } \\
\text { of Vata in the } \\
\text { intestine/ } \\
\text { reverse } \\
\text { peristalsis), } \\
\text { Trita } \\
\text { (thirst/polidip } \\
\text { sia), Kasa } \\
\text { (cough), } \\
\text { Hikka } \\
\text { (hiccup), } \\
\text { Aruchi } \\
\text { (anorexia), } \\
\text { Chardhi } \\
\text { (vomiting), } \\
\text { Atisara } \\
\text { (diarrhoea), } \\
\text { Raktapitta } \\
\text { (bleeding } \\
\text { disorders) }\end{array}$ \\
\hline $\begin{array}{l}\text { Piper } \\
\text { Longum } \\
\text { Linn. }\end{array}$ & $\begin{array}{l}\text { Katu } \\
\text { (pungent } \\
\text { ), } \\
\text { Tikta } \\
\text { (bitter) }\end{array}$ & $\begin{array}{l}\text { Laghu } \\
\text { (lightness } \\
\text { ), } \\
\text { Snigdha } \\
\text { (unctuous } \\
\text { ness), } \\
\text { ushna } \\
\text { (hotness) }\end{array}$ & $\begin{array}{l}\text { Anush } \\
\text { na } \\
\text { (neithe } \\
\text { r hot } \\
\text { nor } \\
\text { cold) }\end{array}$ & $\begin{array}{l}\text { Madhura } \\
\text { (sweet) }\end{array}$ & $\begin{array}{l}\text { Vata- } \\
\text { Kapha } \\
\text { har } \\
\text { (pacifies } \\
\text { Vata\&Ka } \\
\text { phadosha } \\
\text { ) }\end{array}$ & $\begin{array}{l}\text { Deepana } \\
\text { (digestive } \\
\text { enhancer), } \\
\text { Vrisya } \\
\text { (aphrodisia } \\
\text { c), } \\
\text { Rasayna } \\
\text { (rejuvenato } \\
\text { r), } \\
\text { Rechaka } \\
\text { (osmotic } \\
\text { laxative), } \\
\text { Pittala } \\
\text { (increases } \\
\text { Pitta) }\end{array}$ & 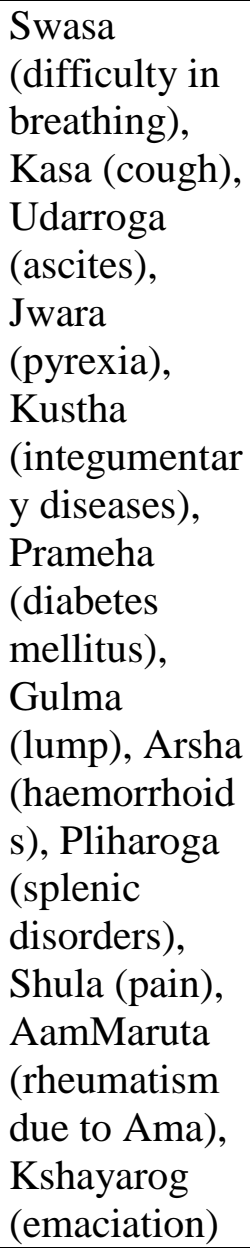 \\
\hline $\begin{array}{l}\text { Cyperus } \\
\text { rotundus } \\
\text { Linn. }\end{array}$ & $\begin{array}{l}\text { Katu } \\
\text { (pungent } \\
\text { ), }\end{array}$ & $\begin{array}{l}\text { Laghu } \\
\text { (lightness } \\
\text { ), Ruksha } \\
\text { (dryness) }\end{array}$ & $\begin{array}{l}\text { Sheeta } \\
\text { (cold) }\end{array}$ & $\begin{array}{l}\text { Katu } \\
\text { (pungent) }\end{array}$ & $\begin{array}{l}\text { Kapha- } \\
\text { Pitta- } \\
\text { Rakta-har }\end{array}$ & $\begin{array}{l}\text { Grahi } \\
\text { (absorptive } \\
\text { ), Pachana }\end{array}$ & $\begin{array}{l}\text { Trishna } \\
\text { (thirst/polidip } \\
\text { sia), Jwara } \\
\text { (pyrexia), }\end{array}$ \\
\hline
\end{tabular}




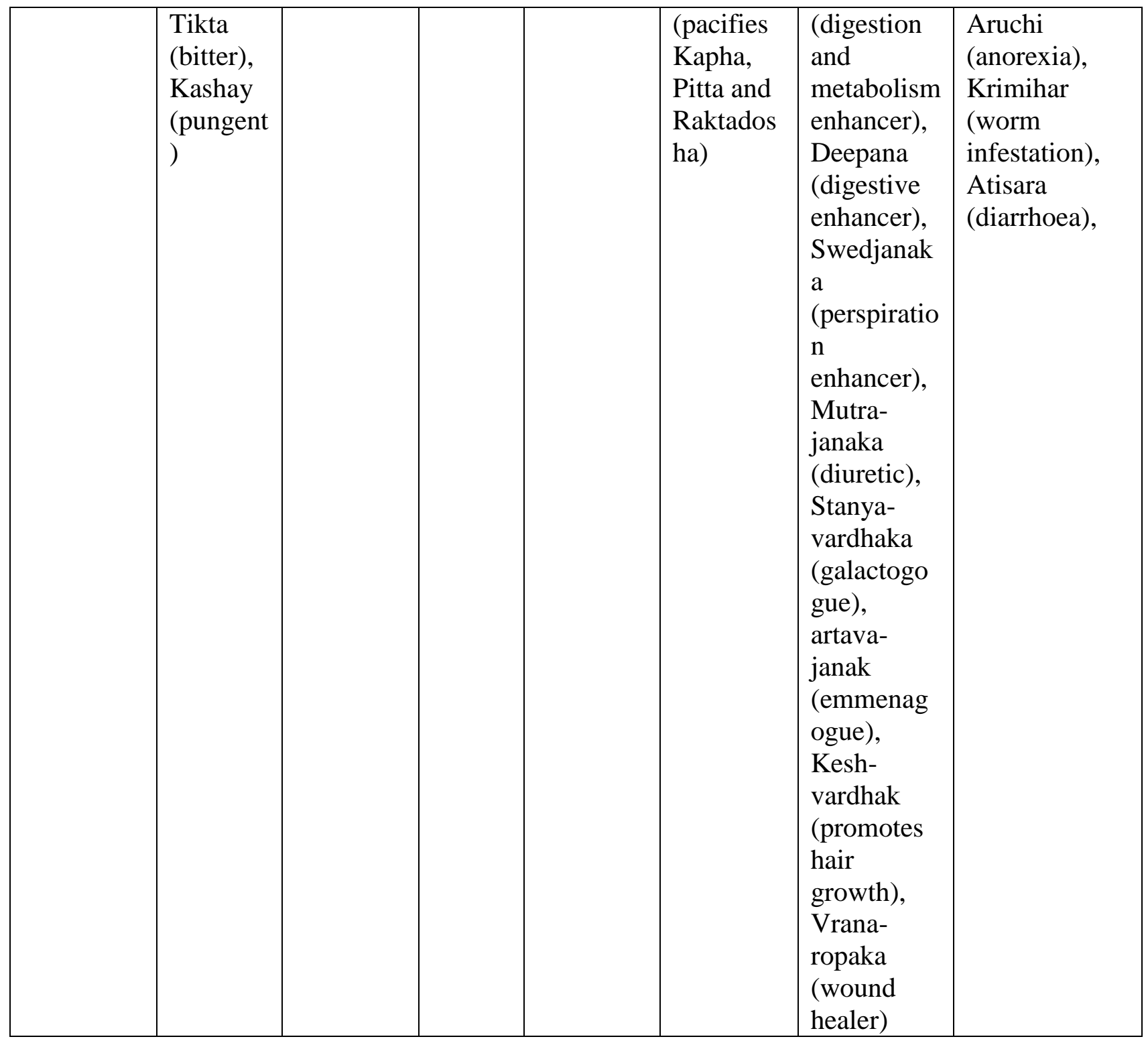

Table no.3: Pharmacological activity of Balchaturbhadrachurna by its ingredients $^{31-65}$

\begin{tabular}{|l|l|}
\hline Medicinal Plant & Pharmacological activities \\
\hline $\begin{array}{l}\text { Aconitum } \\
\text { Wall. }{ }^{31,32,43,54}\end{array}$ & $\begin{array}{l}\text { anti-inflammatory, anti-bacterial, anti-oxidant, anti- } \\
\text { diarrhoeal }\end{array}$ \\
\hline $\begin{array}{l}\text { Pistacia Integerrima } \\
\text { stew. Ex Brandis } \\
64\end{array}$ & $\begin{array}{l}\text { anti-pyretic, anti-spasmodic, anti-diarrheal, anti-asthmatic, } \\
\text { anti-inflammatory, analgesic, }\end{array}$ \\
\hline $\begin{array}{l}\text { Piper Longum } \\
\text { Linn. }\end{array}$ & $\begin{array}{l}\text { an-42,44-46,65 } \\
\text { anti-viral, anti-inflammatic, anti-oxidant, hepatoprotective, } \\
\text { immunomodulator, anti-platelet, analgesic, bioavailability } \\
\text { enhancer, cardioprotective, neuroprotective, antibacterial }\end{array}$ \\
\hline $\begin{array}{l}\text { Cyperus rotundus } \\
\text { Linn. }\end{array}$ & $\begin{array}{l}\text { anti-53,55-59 } \\
\text { anti-convidant, anti-ulcer, analgesic, anti-microbial, cytotoxic, } \\
\text { spasmodic, anti-inflammatory, hepatoprotective, }\end{array}$ \\
\hline
\end{tabular}




\begin{tabular}{|l|l|}
\hline & $\begin{array}{l}\text { cardioprotective, anti-lipidemic, anti-platelet, anti- } \\
\text { depressant, neuroprotective }\end{array}$ \\
\hline
\end{tabular}

Table no. 4: Preclinical Pharmacological and toxicological/ safety studies of Balchaturbhadra churna: ${ }^{66}$

\begin{tabular}{|l|l|}
\hline $\begin{array}{l}\text { Sl. } \\
\text { No. }\end{array}$ & Pre-clinical pharmacological and toxicological / safety studies \\
\hline 1. & $\begin{array}{l}\text { In albino-wistar rats, the acute toxicity experiment showed that the drug did not } \\
\text { produce any signs and symptoms of toxicity (or mortality) up to the dose of } 2000 \\
\mathrm{mg} / \mathrm{kg}\end{array}$ \\
\hline 2. & $\begin{array}{l}\text { Balacaturbhadra churna at dose of } 900 \mathrm{mg} / \mathrm{kg} \text { given for } 45 \text { days has shown mild } \\
\text { toxic potential. }\end{array}$ \\
\hline
\end{tabular}




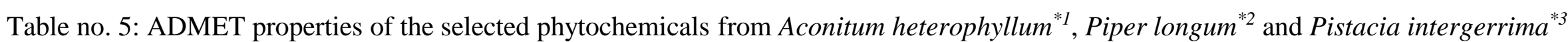

\begin{tabular}{|c|c|c|c|c|c|c|c|c|c|c|c|c|}
\hline Molecule & $\begin{array}{c}\text { Molecul } \\
\text { arweight } \\
\text { (kDa) }\end{array}$ & $\begin{array}{c}\text { No. of } \mathbf{H} \\
- \\
\text { bondacc } \\
\text { eptors }\end{array}$ & $\begin{array}{l}\text { No. ofH- } \\
\text { bond don } \\
\text { ors }\end{array}$ & $\mid \begin{array}{c}\text { TotalSu } \\
\text { rfaceAr } \\
\text { ea }\end{array}$ & $\begin{array}{c}\text { Lipophilici } \\
\text { ty(WLOG } \\
\text { P) }\end{array}$ & Solubility & $\begin{array}{c}\text { GIabsorp } \\
\text { tion }\end{array}$ & $\begin{array}{c}\text { BBBperme } \\
\text { ability }\end{array}$ & \begin{tabular}{|c} 
Pgpsubs \\
trate
\end{tabular} & $\begin{array}{c}\text { CYP3A } \\
\text { 4Inhibi } \\
\text { tor }\end{array}$ & $\mid \begin{array}{c}\log K \\
\mathbf{p}(\mathbf{c m} \\
/ \mathbf{s})\end{array}$ & $\begin{array}{l}\text { Lipinski\# } \\
\text { violations }\end{array}$ \\
\hline $\begin{array}{l}2- \\
\text { hydroxysoorien } \\
\operatorname{tin}^{* 3}\end{array}$ & 465.38 & 12 & 10 & 228.6 & -1.12 & Soluble & Low & No & No & No & -9.5 & 2 \\
\hline Guineesine $^{* 2}$ & 383.52 & 3 & 1 & 47.56 & 5.54 & $\begin{array}{c}\text { Moderately } \\
\text { soluble }\end{array}$ & High & Yes & No & Yes & -3.8 & 0 \\
\hline Pipercide $^{* 2}$ & 341.44 & 3 & 1 & 47.56 & 4.52 & $\begin{array}{c}\text { Moderately } \\
\text { soluble }\end{array}$ & High & Yes & No & Yes & -4.05 & 0 \\
\hline Piperoic acid ${ }^{* 2}$ & 358.47 & 4 & 3 & 77.76 & 5.76 & $\begin{array}{c}\text { Very solubl } \\
\mathrm{e}\end{array}$ & High & Yes & No & No & -6.52 & 0 \\
\hline
\end{tabular}




\section{References:}

1. Eberhardt CS, Siegrist CA. Is there a role for childhood vaccination against COVID-19? Pediatr Allergy Immunol. 2021;32(1):9-16. doi:10.1111/pai.13401

2. Deville JG, Song E, Ouellette CP. COVID-19: Clinical manifestations and diagnosis in children. Up to Date. Published online 2021:1.

https://www.uptodate.com/contents/covid-19-clinical-manifestations-anddiagnosis-in-children

3. Auger KA, Shah SS, Richardson T, et al. Association between Statewide School Closure and COVID-19 Incidence and Mortality in the US. JAMA - J Am Med Assoc. 2020;324(9):859-870. doi:10.1001/jama.2020.14348

4. Parcha V, Booker KS, Kalra R, et al. A retrospective cohort study of 12,306 pediatric COVID-19 patients in the United States. Sci Rep. 2021;11(1):1-10. doi:10.1038/s41598-021-89553-1

5. Adeyinka A, Bailey K, Pierre L, Kondamudi N. COVID 19 infection: Pediatric perspectives. J Am Coll Emerg Physicians Open. 2021;2(1):1-11. doi:10.1002/emp2.12375

6. Patel NA. Pediatric COVID-19: Systematic review of the literature. Am J Otolaryngol - Head Neck Med Surg. 2020;41(5):102573. doi:10.1016/j.amjoto.2020.102573

7. Castagnoli R, Votto M, Licari A, et al. Severe Acute respiratory syndrome coronavirus 2 (SARS-CoV-2) infection in children and adolescents: A systematic review. JAMA Pediatr. 2020;174(9):882-889. doi:10.1001/jamapediatrics.2020.1467

8. Mallapaty S. India's massive COVID surge puzzles scientists. Nature. 2021;592(7856):667-668. doi:10.1038/d41586-021-01059-y

9. WHO-COVID-19-global-data. https://covid19.who.int/table

10. Soutik B. Covid-19: A coronavirus- linked threat to children in India. The British Broadcasting Corporation. https://www.bbc.com/news/world-asiaindia-57551285. Published June 28, 2021.

11. Sharma M. Think Covid-19 is mild among children? Study finds coronavirus turned severe for thousands in India. India today. Published online February 2021. https://www.indiatoday.in/coronavirus-outbreak/story/think-covid-19mild-among-children-study-cases-severe-mis-c-india-1767800-2021-02-10

12. COVID-19 Data Repository by the Center for Systems Science and Engineering (CSSE) at Johns Hopkins University. Center for Systems Science and Engineering (CSSE), Johns Hopkins University. https://github.com/CSSEGISandData/COVID-19

13. Choudhary OP, Dhawan M, Priyanka. Omicron variant (B.1.1.529) of SARSCoV-2: Threat assessment and plan of action. Int J Surg. 2020;97(January). doi:10.1016/j.ijsu.2021.106187

14. Thakur V, Kanta Ratho R. OMICRON (B.1.1.529): A new SARS-CoV-2 Variant of Concern mounting worldwide fear. J Med Virol. 
2021;(December):1-4. doi:10.1002/jmv.27541

15. Welle D. India's surge in Covid-19 infections affecting young children. Hindustan Times. https://www.hindustantimes.com/lifestyle/health/indiassurge-in-covid-19-infections-affecting-young-children-101642214780788.html. Published January 15, 2022.

16. Nayak M. Why COVID Third Wave Affecting Kids More Than 2 Other Waves? Here's What Experts Say. India.com News Desk. Published 2022. https://www.india.com/news/india/covid-third-wave-in-india-latest-news-whythird-wave-affecting-kids-more-than-2-other-waves-heres-what-experts-say-drrandeep-guleria-symptoms-treatment-of-omicron-5186593/

17. Sen M. How Covid-19 in India may change its behavior among children, govt explains. Mint. https://www.livemint.com/news/india/how-covid-19-in-indiamay-change-its-behaviour-among-children-govt-explains11622548706035.html. Published June 1, 2021.

18. Kotecha R. The journey with COVID-19: Initiatives by Ministry of AYUSH. $J$ Ayurveda Integr Med. 2021;12(1):1-3. doi:10.1016/j.jaim.2021.03.009

19. Chopra A, Tillu G, Chuadhary K, et al. Coadministration of AYUSH 64 as an adjunct to Standard of Care in mild and moderate COVID-19: A randomised, controlled, multicentric clinical trial. medRxiv.

2021;(M):2021.06.12.21258345.

http://medrxiv.org/content/early/2021/06/17/2021.06.12.21258345.abstract

20. Ministry of Health and Family Welfare G of I. Guidelines on operationalization of COVID care services for children \& adolescents. Published online 2021. https://www.mohfw.gov.in/pdf/GuidelinesonOperationalizationofCoVIDCareS ervicesforChildrenandAdolescents14062021.pdf

21. Ministry of Ayush G of I. Home care guidelines for children and advisory for AYUSH practitioners about prophylactic care in children during the covid-19 pandemic. Published online 2021. https://main.ayush.gov.in/home-careguidelines-for-children-and-advisory-for-ayush-practitioners-aboutprophylactic-in-children-during-the-covid-19-pandemic/

22. The Ayurvedic Formulary of India, Part 1. $2^{\text {nd }}$ revised ed. Dept. of Indian Systems of Medicine \& Homeopathy, Govt. of India; 2003.

23. Jagdishwar Tripathi. Chakradatta of Shri Chakrapanidatta. Chaukhambha Sanskrit Series, Varanasi; 1946.

24. Vaidya LC. Bhaishajyaratnavali of Shri Govinda Dasa Sen. Mothilal Banarasi Das, Varanasi; 1970.

25. Joshi SS. Yogaratnakara. Chaukhambha Sanskrit Series, Varanasi; 1939.

26. Chunekar KC, G.S Pandey. Bhavprakash Nighantu (Indian Material Medica) of Sri Bhavamisra. Revised ed. Chaukhambha Bharati Academy, Varanasi; 2010.

27. Sharma P, Sharma GP. Kaiyadeva-Nighantuh (Pathyapathya-Vibodhakah). 1st ed. Chaukhambha Orientalia, Varanasi; 1979. 
28. The Ayurvedic Pharmacopoeia of India, Part 1. Vol 3. 1st ed. Ministry of Health and Family Welfare, Govt. of India; 2001.

29. The Ayurvedic Pharmacopoeia of India, Part 1. Vol 1. 1st ed. Ministry of Health and Family Welfare, Govt. of India; 2001.

30. The Ayurvedic Pharmacopoeia of India, Part 1. Vol 4. 1st ed. Ministry of Health and Family Welfare, Govt. of India; 2004.

31. Verma S, Ojha S, Raish M. Anti-inflammatory activity of Aconitum heterophyllum on cotton pellet-induced granuloma in rats. J Med Plants Res. 2010;4(15):1566-1569. doi:10.5897/JMPR09.502

32. Ahmad M, Ahmad W, Ahmad M, Zeeshan M, Shaheen F. Norditerpenoid alkaloids from the roots of Aconitum heterophyllum Wall with antibacterial activity. J Enzyme Inhib Med Chem. 2008;23(6):1018-1022. doi:10.1080/14756360701810140

33. Guo Z, Xu J, Xia J, Wu Z, Lei J, Yu J. Anti-inflammatory and antitumour activity of various extracts and compounds from the fruits of Piper longum L. $J$ Pharm Pharmacol. 2019;71(7):1162-1171. doi:10.1111/jphp.13099

34. Bi Y, Qu PC, Wang QS, et al. Neuroprotective effects of alkaloids from Piper longum in a MPTP-induced mouse model of Parkinson's disease. Pharm Biol. 2015;53(10):1516-1524. doi:10.3109/13880209.2014.991835

35. Kaushik D, Rani R, Kaushik P, Sacher D, Yadav J. In vivo and in vitro Antiasthmatic Studies of Plant Piper longum Linn. Internaltional J Pharmacol. 2012;8(3):192-197. doi:10.3923/ijp.2012.192.197

36. Natarajan KS, Narasimhan M, Shanmugasundaram KR, Shanmugasundaram ERB. Antioxidant activity of a salt-spice-herbal mixture against free radical induction. J Ethnopharmacol. 2006;105(1-2):76-83. doi:10.1016/j.jep.2005.09.043

37. Koul IB, Kapil A. Evaluation of the liver protective potential of piperine, an active principle of black and long peppers. Planta Med. 1993;59(5):413-417. doi:10.1055/s-2006-959721

38. Christina AJM, Saraswathy GR, Heison Robert SJ, et al. Inhibition of CCl4induced liver fibrosis by Piper longum Linn.? Phytomedicine. 2006;13(3):196198. doi:10.1016/j.phymed.2004.01.009

39. Tripathi DM, Gupta N, Lakshmi V, Saxena KC, Agrawal AK. Antigiardial and immunostimulatory effect of Piper longum on giardiasis due to Giardia lamblia. Phyther Res. 1999;13(7):561-565. doi:10.1002/(SICI)10991573(199911)13:7<561::AID-PTR479>3.0.CO;2-W

40. Sunila ES, Kuttan G. Immunomodulatory and antitumor activity of Piper longum Linn. and piperine. J Ethnopharmacol. 2004;90(2-3):339-346. doi:10.1016/j.jep.2003.10.016

41. Park B-S, Son D-J, Choi W-S, et al. Antiplatelet Activities of Newly Synthesized Derivatives of Piperlongumine. Phyther Res. 2008;22(4):11951199. doi:10.1002/ptr.2432 
42. Vedhanayaki G, Shastri G V, Kuruvilla A. Analgesic activity of Piper longum Linn. root. Indian J Exp Biol. 2003;41:649-651.

43. Ahmad H, Ahmad S, Shah SAA, et al. Antioxidant and anticholinesterase potential of diterpenoid alkaloids from Aconitum heterophyllum. Bioorganic Med Chem. 2017;25(13):3368-3376. doi:10.1016/j.bmc.2017.04.022

44. Khajuria A, Thusu N, Zutshi U. Piperine modulates permeability characteristics of intestine by inducing alterations in membrane dynamics: Influence on brush border membrane fluidity, ultrastructure and enzyme kinetics. Phytomedicine. 2002;9(3):224-231. doi:10.1078/0944-7113-00114

45. Wakade AS, Shah AS, Kulkarni MP, Juvekar AR. Protective effect of Piper longum L. on oxidative stress induced injury and cellular abnormality in adriamycin induced cardiotoxicity in rats. Indian J Exp Biol. 2008;46(7):528533.

46. Naika R, Prasanna KP, Ganapathy PSS. Antibacterial activity of piperlongumine an alkaloid isolated from the methanolic root extract of Piper longum L. Pharmacophore. 2010;1(2):141-148.

47. Kamala A, Middha SK, Gopinath C, Sindhura HS, Karigar CS. In vitro Antioxidant Potentials of Cyperus rotundus L. Rhizome Extracts and Their Phytochemical Analysis. Pharmacogn Mag. 2018;14(54):261-267. doi:10.4103/pm.pm_228_17

48. Ahmad M, MahayRookh, Rehman A Bin, et al. Assessment of antiinflammatory, anti-ulcer and neuro- pharmacological activities of Cyperus rotundus Linn. Pak J Pharm Sci. 2014;27(6):2241-2246.

49. Ahmad M, Bin Rehman A, Jahan N. Analgesic, Antimicrobial and Cytotoxic Effect of Cyperus Rotundus Ethanol Extract. Pakistan J Pharmacol. 2012;29(2):7-13. http://pakjp.pk/articles/25122012012754.pdf

50. Khalili M, Kiasalari Z, Roghani M, Azizi Y. Anticonvulsant and antioxidant effect of hydroalcoholic extract of Cyperus rotundus rhizome on pentylentetrazole-induced kindling model in male mice. J Med Plants Res. 2011;5(7):1140-1146.

51. Daswani P, Brijesh S, Tetali P, Birdi T. Studies on the activity of Cyperus rotundus Linn. tubers against infectious diarrhea. Indian J Pharmacol. 2011;43(3):340-344. doi:10.4103/0253-7613.81502

52. Shamkuwar PB, Hoshamani AH, Gonjari ID. Antispasmodic effect of Cyperus rotundus L. (Cyperaceae) in diarrhoea. Der Pharm Lett. 2012;4(2):522-524.

53. Dang GK, Parekar RR, Kamat SK, Scindia AM, Rege NN. Antiinflammatory activity of Phyllanthus emblica, Plumbago zeylanica and Cyperus rotundus in acute models of inflammation. Phyther Res. 2011;25(6):904-908. doi:10.1002/ptr.3345

54. Prasad SK, Jain D, Patel DK, Sahu AN, Hemalatha S. Antisecretory and antimotility activity of Aconitum heterophyllum and its significance in treatment of diarrhea. Indian J Pharmacol. 2014;46(1):82-87. doi:10.4103/0253-7613.125182 
55. Bahi A, Necib Y. Hepatoprotective and antioxidant activity of aqueous extract of Cyperus rotundus rhizome against mercuric chloride induced oxidative stress in rats. Int J Pharm Sci Rev Res. 2014;27(1):117-123.

56. Jahan N, Khalil-Ur-Rahman, Ali S. Cardioprotective and antilipidemic potential of Cyperus rotundus in chemically induced cardiotoxicity. Int J Agric Biol. 2012;14(6):989-992.

57. Seo EJ, Lee DU, Kwak JH, Lee SM, Kim YS, Jung YS. Antiplatelet effects of Cyperus rotundus and its component (+)-nootkatone. J Ethnopharmacol. 2011;135(1):48-54. doi:10.1016/j.jep.2011.02.025

58. Hao GF, Tang MQ, Wei YJ, Che FY, Qian LJ. Determination of antidepressant activity of cyperus rotundus 1 extract in rats. Trop J Pharm Res. 2017;16(4):867-871. doi:10.4314/tjpr.v16i4.17

59. Hemanth Kumar K, Tamatam A, Pal A, Khanum F. Neuroprotective effects of Cyperus rotundus on SIN-1 induced nitric oxide generation and protein nitration: Ameliorative effect against apoptosis mediated neuronal cell damage. Neurotoxicology. 2013;34(1):150-159. doi:10.1016/j.neuro.2012.11.002

60. Rauf A, Uddin G, Siddiqui BS, et al. In-vivo antinociceptive, antiinflammatory and antipyretic activity of pistagremic acid isolated from Pistacia integerrima. Phytomedicine. 2014;21(12):1509-1515. doi:10.1016/j.phymed.2014.07.015

61. Shirole RL, Shirole NL, Saraf MN. In vitro relaxant and spasmolytic effects of essential oil of Pistacia integerrima Stewart ex Brandis Galls. $J$ Ethnopharmacol. 2015;168:61-65. doi:10.1016/j.jep.2015.02.001

62. Alhumaydhi FA, Rauf A, Rashid U, et al. In Vivo and in Silico Studies of Flavonoids Isolated from Pistacia integerrima as Potential Antidiarrheal Agents. ACS Omega. 2021;6(24):15617-15624. doi:10.1021/acsomega.1c00298

63. Shirole RL, Shirole NL, Kshatriya AA, Kulkarni R, Saraf MN. Investigation into the mechanism of action of essential oil of Pistacia integerrima for its antiasthmatic activity. J Ethnopharmacol. 2014;153(3):541-551. doi:10.1016/j.jep.2014.02.009

64. Ahmad NS, Waheed A, Farman M, Qayyum A. Analgesic and antiinflammatory effects of Pistacia integerrima extracts in mice. $J$ Ethnopharmacol. 2010;129(2):250-253. doi:10.1016/j.jep.2010.03.017

65. Priya N., Kumari S. Research Article Antiviral Activities and Cytotoxicity Assay of Seed Extracts of Piper longum and Piper nigrum on Human Cell Lines. Int J Pharm Sci Rev Res. 2017;44(42):197-202.

66. Nariya MB, Parmar P, Shukla VJ, Ravishankar B. Toxicological study of balacaturbhadrika churna. J Ayurveda Integr Med. 2011;2(2):79-84. doi:10.4103/0975-9476.82526

67. Jin Z, Du X, Xu Y, et al. Structure of Mpro from SARS-CoV-2 and discovery of its inhibitors. Nature. 2020;582(7811):289-293. doi:10.1038/s41586-020$2223-y$ 
68. Wang Q, Zhang Y, Wu L, et al. Structural and Functional Basis of SARS-CoV2 Entry by Using Human ACE2. Cell. 2020;181(4):894-904.e9. doi:10.1016/j.cell.2020.03.045

69. Gao Y, Yan L, Huang Y, et al. Structure of the RNA-dependent RNA polymerase from COVID-19 virus. Science (80- ). 2020;368(6492):779-782. doi:10.1126/science.abb7498

70. Koulgi S, Jani V, Uppuladinne M, et al. Drug repurposing studies targeting SARS-CoV-2: an ensemble docking approach on drug target 3C-like protease (3CLpro). J Biomol Struct Dyn. 2020;0(0):1-21. doi:10.1080/07391102.2020.1792344

71. Koulgi S, Jani V, Uppuladinne VNM, Sonavane U, Joshi R. Structural insight into the binding interactions of NTPs and nucleotide analogues to RNA dependent RNA polymerase of SARS-CoV-2. J Biomol Struct Dyn. 2021;0(0):1-15. doi:10.1080/07391102.2021.1894985

72. Jani V, Koulgi S, Uppuladinne VNM, Sonavane U, Joshi R. An insight into the inhibitory mechanism of phytochemicals and FDA-approved drugs on the ACE2-Spike complex of SARS-CoV-2 using computational methods. Chem Pap. 2021;75(9):4625-4648. doi:10.1007/s11696-021-01680-1

73. Case DA, Betz RM, Cerutti DS, et al. Amber 2016. Univ California, San Fr. Published online 2016.

74. Allen WJ, Balius TE, Mukherjee S, et al. DOCK 6: Impact of new features and current docking performance. J Comput Chem. 2015;36(15):1132-1156. doi:10.1002/jcc.23905

75. RA L, MB S. LigPlot+: multiple ligand-protein interaction diagrams for drug discovery. J Chem Inf Model. 2011;51:2778-2786.

76. Daina A, Michielin O, Zoete V. SwissADME: A free web tool to evaluate pharmacokinetics, drug-likeness and medicinal chemistry friendliness of small molecules. Sci Rep. 2017;7(January):1-13. doi:10.1038/srep42717

77. Zhao Z, Bourne PE. Structural Insights into the Binding Modes of Viral RNADependent RNA Polymerases Using a Function-Site Interaction Fingerprint Method for RNA Virus Drug Discovery. J Proteome Res. 2020;19(11):46984705. doi:10.1021/acs.jproteome.0c00623

78. Paramanick D, Panday R, Shukla SS, Sharma V. Primary Pharmacological and Other Important Findings on the Medicinal Plant "Aconitum Heterophyllum" (Aruna). J Pharmacopuncture. 2017;20(2):89-92. doi:10.3831/KPI.2017.20.011

79. Ukani MD, Mehta NK, Nanavati DD. Aconitum heterophyllum (ativisha) in ayurveda. Anc Sci Life. 1996;16(2):166-171.

http://www.ncbi.nlm.nih.gov/pubmed/22556788\%0Ahttp://www.pubmedcentra 1.nih.gov/articlerender.fcgi?artid=PMC3331153

80. Bibi Y, Zia M, Qayyum A. An overview of Pistacia integerrima a medicinal plant species: Ethnobotany, biological activities and phytochemistry. Pak J Pharm Sci. 2015;28(3):1009-1013. 
81. Venkatasubramanian P, Kumar K. S, Nair VSN. Cyperus rotundus, a substitute for Aconitum heterophyllum: Studies on the Ayurvedic concept of Abhava Pratinidhi Dravya (drug substitution). J Ayurveda Integr Med. 2010;1(1):33-39. doi:10.4103/0975-9476.59825

82. Yadav V, Krishnan A, Vohora D. A systematic review on Piper longum L.: Bridging traditional knowledge and pharmacological evidence for future translational research. J Ethnopharmacol. 2020;247:112255. doi:10.1016/j.jep.2019.112255 